\title{
The Challenges of Human Capital Performance in Developing Baitul Maal Wat Tamwil in Indonesia
}

\author{
Aas Nurasyiah, Suci Aprilliani Utami, A. Jajang. W. Mahri, Firmansyah \\ Department of Islamic Economics and Finance \\ Universitas Pendidikan Indonesia \\ Bandung, Indonesia \\ asnur.fna@upi.edu
}

\begin{abstract}
One of the problem in the development of Baitul Maal Wat Tamwil is human capital. It was due to the lack of BMT practitioners who understand the principles of good business management and sariah at once. Therefore, BMT as an Islamic Microfinance Institution is considered to be less competitive compared to other Islamic financial institutions or operating system which is not in line with Sariah compliance. Human capital is defined as the knowledge, skills and experience of workers which can be contributed to the organization of the company / institution. Basic theory used is the General Theory of Human Capital and Human Capital in Islamic Perspectives. In Islamic Human Capital Development Theory, it urgues the improvement of education, skills and human being in Islamic theory which is more comprehensively in this regard, as it covers every aspect of development of a human being. The study was conducted to reveal the profile of human capital owned BMT and some of the factors that are considered to be a challenge in building employee performance of BMT. Empirical study of this research used Analytical Network Process. The amount of respondent consists of three experts (Cooperative ministry and Small and medium enterprises; Puskopsyah; Academician of UPI) and five practitioners (BMT EI Dana Manfaat; BMT Itqan; BMT Dana Ukhuwah; BMT Baiturrahim; and BMT Daarut Tauhid). Respondent is expert and practitioners where in Bandung and the data collecting by interview. Based on the results of this research note that the motivation and the Islamic financial literacy BMT employee becomes a major problem. The best solution of this problem selected by the practitioner and the expert is an employee assistance BMT, the implementation of intensive training and selection process that regard between sharia knowledge and managerial skills. Therefore, this research is expected to improve the existence of BMT as Islamic Microfinance Institution for the welfare of the community.
\end{abstract}

Keywords- Human Capital, Baitul Maal Wat Tamwil and Analytical Network Process

\section{INTRODUCTION}

Baitul Maal Wat Tamwil (BMT) is the simplest form of Islamic Financial Institutions, most of them diversified business entities cooperatives [1]. The existence of such an enterprise is fueled by a very limited opportunities to establish formal Islamic bank in the form of Commercial Bank or Sharia Rural Bank (BPRS). Unlike the commercial banks and the BPRS is explicitly regulated by the Banking Act No. 10, 1998. The BMT is a legal entity governed cooperative in the regulation of the minister of Cooperatives and Small and Medium Enterprises of the Republic of Indonesia, namely Decree Kop SMEs No. 91 / Kep / M. KUKM / IX / 2004 on guidelines for the operational units of the Islamic financial services cooperatives and Islamic financial services unit. The main thing that distinguishes BMT with other Islamic financial institutions is market segmentation that is at the micro level, so it is often referred to as Islamic microfinance institution.

BMT developments in Indonesia by [2] can be seen from BMT link which estimated in 2006 at 3,200 with the number of customers as many as 3 million people, and then until the end of 2010 grew to approximately 5,200 customers BMT to serve 10 million people. Muhammad Kholim [2] mentions that the three areas that have a number of BMT in Indonesia are West Java with 637 BMT (433 BMT reported its activities to PINBUK), East Java with 600 BMT (519) BMT reported activities) and Central Java ranks third with 513 BMT (BMT 447 reported activities). Given the importance to the national economy especially BMT indirect impact on the growth of the Islamic banking industry. Additionally, based on data from the Ministry of Cooperatives and Micro, Small and Medium Enterprises (SMEs), until the end of 2011 a cooperative unit in general totaled 187598 cooperative units, of which 71365 units a savings and loan cooperative, and approximately 5,500 units $(7,7$ per cent) of them were BMT.

Based on data from BMT developments mentioned above, then Indonesia has tremendous potential in improving the financial industry that are inclusive and significantly contributed in the development of the real sector at a lower level (SMEs business operators). However, based on the results of previous studies mentioned that the development of BMT in Indonesia still faced with some problems, as revealed by[3] issue of good management (39\%), human resources skills (37\%) and capital adequacy (17\%). [3] Concluded that the issue of human resources, engineering, legal / structural and market / communal major obstacles to the development of the BMT in Indonesia. [2] Said the main obstacle faced by administrators in the management of BMT is the problem of capital (56.15 percent). Besides the constraints faced board is also quite prominent BMT is a matter of competence of human resources (15.24 percent) and competition (12.83 percent) and government regulations are not conducive also quite an obstacle in the management of BMT (12.04 percent).

Thus, the issue of competence, skills and human resources performance of BMT (human capital) became an important 
part that must be considered in establishing BMT in Indonesia. Based on the mapping and potential BMT conducted by Bank Indonesia which surveyed HR profile BMT in Java, it is known that the average BMT has 12 employees while most BMT has only five employees. BMT is generally stated that the turn-over of employees is very low (50.27 per cent), even BMT in Central Java that states low and very low reached 85.35 percent. This fact shows that the relative BMT has no problems in the aspect of employee loyalty to the BMT. The educational background of the majority of managers and junior high school education (52.40 percent). While the average wage of employees BMT (all levels) reached 958.343, IDR 00 with the mode of 1 million IDR. The average wage is certainly far below the average wage of employees of Islamic banks are estimated to reach 4 million IDR to 5 million IDR [2].

Another major factor that is still considered to be a problem in building human capital BMT is the competence of human resources that have professional skills and knowledge in financial matters sharia simultaneously. Based on the results of research conducted by [4] that most managers and employees BMT has no educational background in economics and Islamic finance as well as a good knowledge and understanding of the main principles in the Islamic financial. This condition is very worrying, given BMT as a manifestation of Islamic Microfinance Institution should have a good Sariah compliance in conducting business and it begins with the human resource competency BMT has the Islamic financial literacy. Therefore, this paper would like to express how the obstacles encountered in HR performance BMT as human capital to build a BMT in Indonesia.

\section{LITERATURE REVIEW}

\section{A. Islam and Human Capital Development}

Human Capital is a theory that was first introduced by Western scientists. Human resource development in the context of the public, human capital is understood as the skills, abilities, knowledge and experience of the people to do their job. Thus, the development of human resources is the process of improving the skills and competence of human resources by investing in developing their competencies such as providing training, education and human resource management are good. For example, in the organization of the staff is an intangible asset or capital organization. In order to improve the human capital of the organization providing training, internships and so on [5].

The success of a company depends on the quality of its human resources. Therefore, companies need to invest into Human capital to make a profit. According to [6] make expenditures for education, training, medical care, and so as a form of Human capital investment. Theories of human capital in the general context does not emphasize on the development of moral values. Although [6] said moral values as part of human capital, but in theory Human Capital Smith moral values do not exist. In fact, there is no doubt that the moral values have a major contribution to achieving success in development.

In the viewpoint of Islam, the development of skills and abilities have different goals and objectives. In addition, the development dimension in Islam has a broader meaning. [5]
The development of human resources is to increase the ability of people so that they can offer more services to the community in both. The final goal of community development is to meet the goal of the creation of man is worship to Allah SWT. So, in the context of Islam meaning of Human Capital is the human ability and experience to meet the objectives and responsibilities. Verses mentioned above describe the objectives and responsibilities of human life that became caliph in the earth. That is the theory of human capital differences within Islam. While in a general context, the purpose of human resource development is to achieve economic growth. Then in Islam, human resource development goal is to achieve the quality and competence to fulfil the duties and responsibilities ordained by Allah SWT.

The development of human capital in Islam covers all kinds of aspects of the development of physical, intellectual, psychological and spiritual. Thus, Islam in contrast to the general theory of human capital heed the spiritual aspect of human additionally, the theory of Islamic economics is largely based on the equation. Focusing on the collective but in contrast to communism because Islam also appreciate the work and abilities of each individual.

However, although the concept of Islam similar to the Western idea both of concept emphasis on the development of knowledge, skills and human experience to improve the competence of broader human. Islam is a religion that contributes a lot to motivate people to improve their knowledge, skills and competencies. Islam motivates the development of mental, physical, intellectual and human ethics or in other words a more comprehensive human development.

\section{B. Human Capital Performance}

Human Capital is the potential for the organization in the form of individual knowledge are hidden, namely the skills necessary to perform its functions in the organization. Human capital is the lifeblood of intellectual capital as a source of innovation, improvisation, and a very useful knowledge, skills and competencies within an organization or company, but is a component that is difficult to measure [5].

Performance is a complex concept. One will agree that a BMT is said to perform well when they have several criteria, such as growth, profitability, which could be seen from financial statements [7]. Moreover, the term used in Islamic banking. BMT must be healthy. The healthiness can be represented as having been growing well within the period in study. According to this understanding, we define the good performance as those which have been operating two years or more and they are experiencing growth in:
1) total asset
2) number of depositors or customers
3) total outstanding projects being financed

Professional management is the most important to developing BMT. But, it is not arguable that education of the management, salary of the management and working hours are all the content of professional management. So, the variable will be assumed to be a proxy through the content items [3]. 


\section{Baitul Maal Wat Tamwil}

Baitul Maal Wat Tamwil (BMT) is an Islamic economic institutions which is a modification of existing Baitul Maal in the period of the Prophet Muhammad. Unlike Baitul Maal, BMT is not only a social role that non -profit, but also plays an important role in the commercial with the profit motive through economic functions. There are four activities undertaken by BMT [7], which collect and distribute zakat, infaq, shodaqoh and wakaf, financing activities, financing and services. In financing activities, BMT is generally used wadiah and mudharabah agreement, for financing activities using mudharabah and musharakah, as well as to the activity of BMT services using kafalah contract, Ijarah, Hiwalah, wakalah and Rahn.

The word Baitul Mal Wat Tamwil (BMT) comes from the two terms, i.e., baitul mal and baitul tamwil [8]. As such, a more specific definition can be derived as follows:

1) Baitul mal means the house of wealth which refers to the social mission of BMT as an institution that distributes the donation of zakat, infaq, and shadaqah to the persons who are eligible to receive (Mustahiq).

2) Baitul tamwil means the house of wealth development, which is the business mission of BMT. It is meant to conduct business development efforts and investments in productive economy in order to improve the quality of micro and small entrepreneurs, especially, by encouraging saving activities and supporting the financing of economic activities.

\section{METHODOLOGY}

\section{A. Data Source}

This research is using primary data which is obtained by doing in-depth interview with experts and practitioners to understand the problem comprehensively. In order to synthesize the problems and make it in priority, second meeting (interview) with experts and practitioners is needed to complete pair-wise questionnaires. The amount of respondent consists of three experts (Cooperative ministry and small and medium enterprises; Puskopsyah; Academician of UPI) and five practitioners (BMT El Dana Manfaat; BMT Itqan; BMT Dana Ukhuwah; BMT Baiturrahim; and BMT Daarut Tauhid). Respondent is expert and practitioners where in Bandung. There is no maximum or minimum quotes to choose respondent, the most important things to be considered is they must have good ability and good understanding about Baitul maal wat Tamwiil (BMT).

\section{B. ANP Methodology}

Analytical Network Process (ANP) is one of the methods of decision-making based on many criteria or Multiple Decision Making (MCDM). Excess ANP from another methodology that is easily applied to a variety of qualitative studies, such as decision making, forecasting (forecasting), strategizing, resource allocation and so forth [9].

ANP is the new approach to qualitative methods. ANP was introduced by Professor Thomas Saaty, with the intention to refine the method of Analytic Hierarchy Process (AHP). ANP exceeds the other methodologies in its ability to take measurements, and to synthesize a number of factors in a hierarchy or network. No other methodologies have these facilities, such as the synthesis of ANP methodology. ANP is used to derive composite priority ratio scales from individual ratios that reflect the relative measurement of the influence of elements which interact with each other with respect to the control criteria. ANP is a mathematical theory that allows one to treat dependence, and with its feedback, can systematically capture and combine factors that are tangible as well as intangible [10].

Figure 1. Ilustrates the analytical network process (ANP) research stages according ascarya [3]. The process consists of three phase, there are phase 1 (model construction), phase 2 (model quantification) and phase 3 (result analysis).

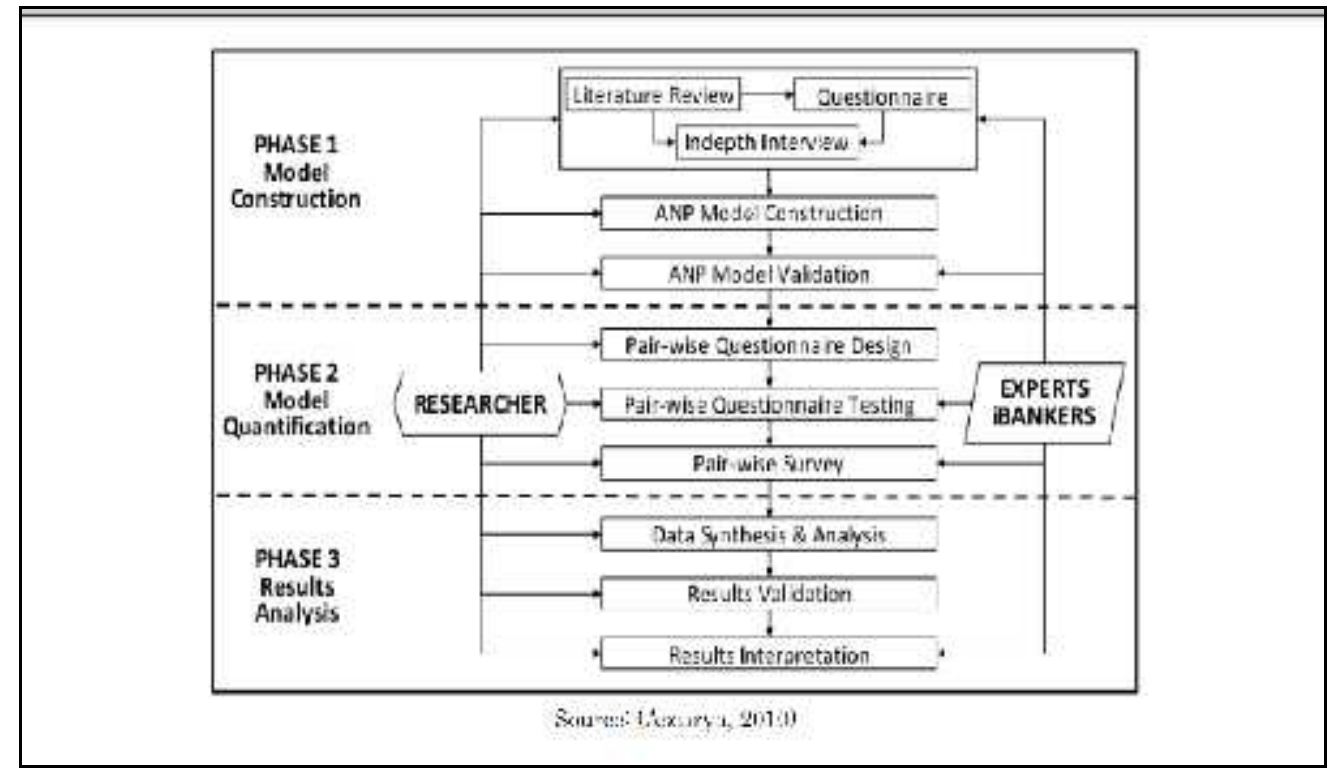

Fig. 1 The ANP research stages, Source : Ascarya [3] 


\section{FINDING AND DISCUSSION}

The common problem of human capital BMT performance is the lack of understanding on the development of business and at the same BMT Sharia principles. This is due to the lack of human resources in the fields of economics and Islamic finance are well educated and professionally especially on technical managerial skills, so in practice BMT often deviated from Islamic principles and cannot run a good business management [3].

The problem of human capital performance in BMT can be divided into four issues, namely: 1) the lack of human resources that have spiritual in developing Islamic financial (motivation), 2) lack of human resources that have managerial skills in developing good business management BMT, 3) lack of human resources who have an understanding of economic principles and Islamic finance, 4) lack of human resources that have the commitment and loyalty to the organization. Each cluster of the problems identified background of the problem based on interviews with the experts and practitioners.

\section{A. Identification of Problem}

1) Lack of Human Resources has a Missionary Zeal In Developing Islamic Financial (Motivation)

Based on the research in the field, it is known that BMT is often difficult to find human resources who want to join to work on developing Islamic finance in BMT. There are many reasons that cause this to happen including the business scope of BMT is relatively small with the segmentation of society at the grass root level, so that when personnel/ employee does not understand the significance of the activity of BMT as part of the propaganda in the fight against loan sharks in society, it will be easy for the employee to resign from BMT. The grounds of compensation earned considered comparable to the task at hand.

\section{2) Lack of Human Resources That Have Good Managerial} Skills In Developing Business Management BMT

BMT is generally started from the small business unit and initiated by the public has limited business scope with limited human resources capacity as well, so that the human resource capabilities in managing professionally BMT is limited. The main factor of them is they have a formal education background is low with less scientific field that matches with the job. In addition, the lack of training that can be followed in developing the human resource capacity available. This is due to budget constraints and lack of training are applicable to be followed by the management of BMT. Thus, in the end the ability to manage BMT obtained autodidact.

3) Lack of Human Resources That Have an Understanding of Economic Principles and Islamic Finance

Implementation of the sharia compliance is the central feature of doing business in the field of Islamic financial. However, in practice known many officers and employees of BMT have a low financial literacy. This condition is very worrying, because it will impact on the understanding of the community (members BMT) who cannot distinguish the main principles in the Islamic financial and image of people who think that financial products and services offered by BMT same with other conventional financial institutions. Factors that cause this problem is the manager of BMT on average do not have a background in formal and informal education in the field of Islamic financial. In addition, the lack of training given by stakeholders to improve Islamic financial literacy for practitioners BMT. During surveillance of Sariah compliance rely on the Sharia Supervisory Board, but from some of the results of field studies of existing Sharia Supervisory Board at BMT lack the capability of controlling the implementation of Islamic principles of activity of BMT.

\section{4) Lack of Human Resources That Have The Commitment} and Loyalty to The Organization

The commitment and loyalty that can be provided by the administrators and managers of the key of the BMT to develop its business. In reality, BMT is often difficult to get human resources with a good commitment and loyalty. The main cause is due to the inability of BMT in providing high compensation for employees. Average for BMT emerging, cannot pay an employee with a standard minimum wage. Thus, become commonplace for BMT to break in new employees. In addition, the creation of the cultural climate of the organization's work is less attention, even though it is becoming an important part in motivating employees to stay contribute to developing the BMT.

\section{B. ANP Results}

Based on Geometric Mean Overall Result The result show that statistically, a consensus of experts and practitioners related to the problem of Human Capital Performance in Developing Baitul Maal Wat Tamwil (BMT). Figure 2 shows the priority issues, the result concluded that the problem of lack of motivation in developing the Islamic financial and lack of understanding of Islamic financial principles are the two major aspects considered important, with Considerable rater agreement $(\mathrm{W}=0.608)$. Overall, as a result of the experts think that the motivation of the manager of BMT to be the most important points in the development of BMT. Followed by problems of Islamic financial literacy skills and managerial capabilities and the latest issue of commitment and loyalty to the organization.

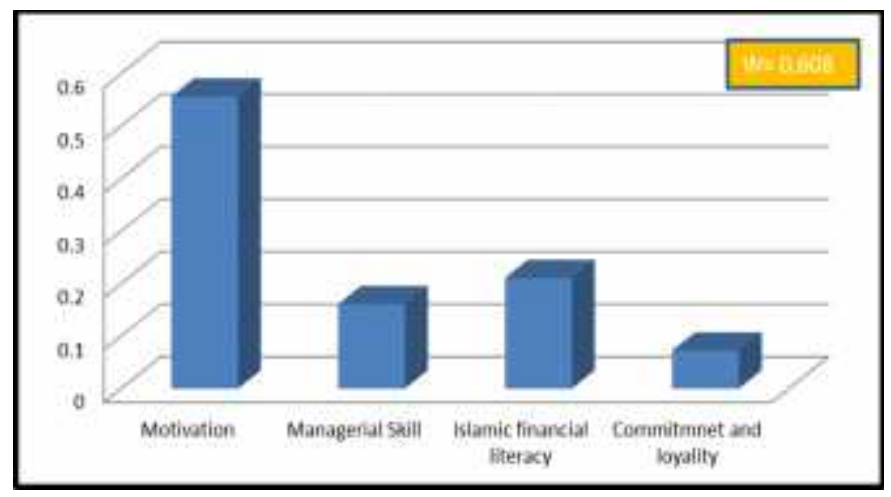

Fig. 2 Problem Priotization, Source : The Data Processing

Based on the priority problem, then the solution proposed by the practitioners and experts to improve human capital performance are: 1) Provide intensive training to practitioners and managers BMT, 2) Make a comprehensive selection of 
human resources BMT, 3) Optimization of mentoring and supervision, 4) Giving reward and punishment.

In prioritization of solution aspects, as shown in Figure 3, both scholars and practitioners agree that the top priority solution is mentoring an employee / manager of BMT in carrying out its activities by the stakeholders (PINBUK, Department of Cooperatives and SMEs, Sharia Council) with the value of rater agreement $(\mathrm{W}=0597)$. Next solution roommates get concern from experts and practitioners is that a comprehensive selection of human resources of BMT managerial skills with the capability of Islamic financial literacy at the same time, implementation of intensive training for the managers of BMT and reward and punishment. Rater agreement is high enough, amounting to 0597 Showed that both experts/ academics and practitioners agree in determining the relative priority aspects of the solution of human capital in the developing performance of BMT in Indonesia.

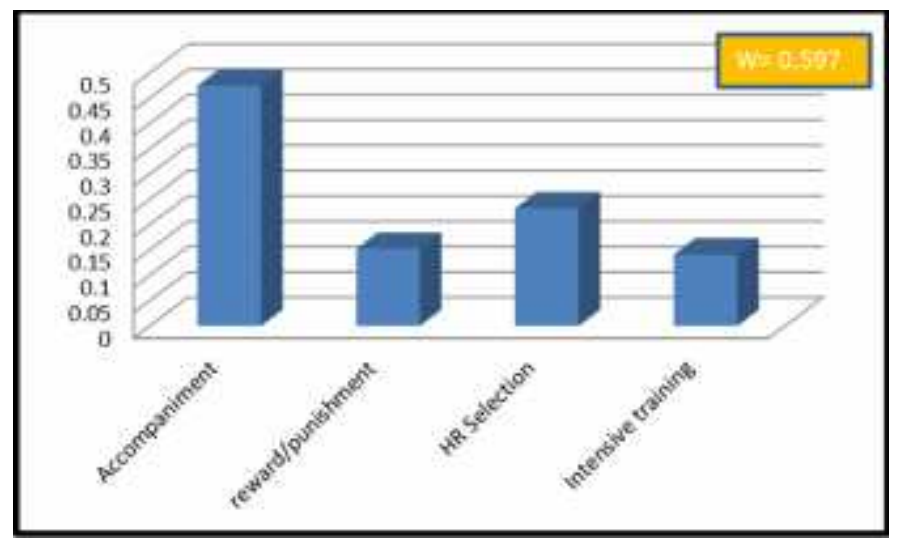

Fig 3.Solution Priotization, Source : The Data Processing

In implementing the required of solution, the periodization strategy is needed. For strategy aspects, as shown in Figure 4 Consist of geometric mean, overall results show for experts and practitioners, the most priority strategy is the creation of organizational culture in accordance with the values of Islam. This strategy became the answer to problems related to human capital performance in BMT such as low motivation of BMT managers and the lack of commitment and loyalty to the organization. Based on the results of previous studies [11] the creation of organizational culture positive and significant impact on performance.

The second strategic priority is to encourage the establishment of educational institutions (SMK / D3) in the field of Islamic Microfinance, this strategy became the answer to several problems related to human capital performance in BMT such as lack of managerial skills possessed human resources BMT in conducting good business management BMT at once have low financial literacy. Promote the establishment of vocational high education institutions and D3 specialized in the field of Islamic Microfinance with the goal to produce human resources that have specific expertise in managing BMT and other Islamic Micro Finance Institutions with Islamic financial literacy levels are good [12]. Given all this time, the human resources available in the BMT majority are graduates of senior secondary education / vocational school that did not receive a formal education in the field of Islamic Microfinance. In addition, graduates of vocational and D3 fields of Islamic Microfinance is considered enough to become a professional organizer in BMT. The S1 education graduates tend to be less interested in working for BMT with the reasons the issue of compensation is deemed to be low and accelerating career at BMT slower than working in other Islamic financial institutions. Examples of educational institutions that $h$ ave opened Islamic Microfinance D3 program is as practiced by STEI Tazkia.

The third and fourth strategies are further strengthening coordination with PINBUK and the University in organizing training for BMT and Linkage Program between BPRS and BMT-BUS. Although it is not a top priority, but this is a complementary strategy which is equally important. The reason is that Islamic financial institutions emerging in Indonesia continues to require the synergy between academics in college with practitioners in the Islamic finance industry that develops between science and practice in line hand in hand [13]. In addition, Islamic Banks and BPRS could be partners in running the business BMT also help increase the competencies of managers BMT especially in terms of managerial skills to be more professional, because basically Islamic Bank operational techniques and BMT management is the same. Overall result shows that the strategy on priority rater agreement has low value $(\mathrm{W}=0308)$. This implied that respondents' answers related to prioritization of this strategy is more varied.

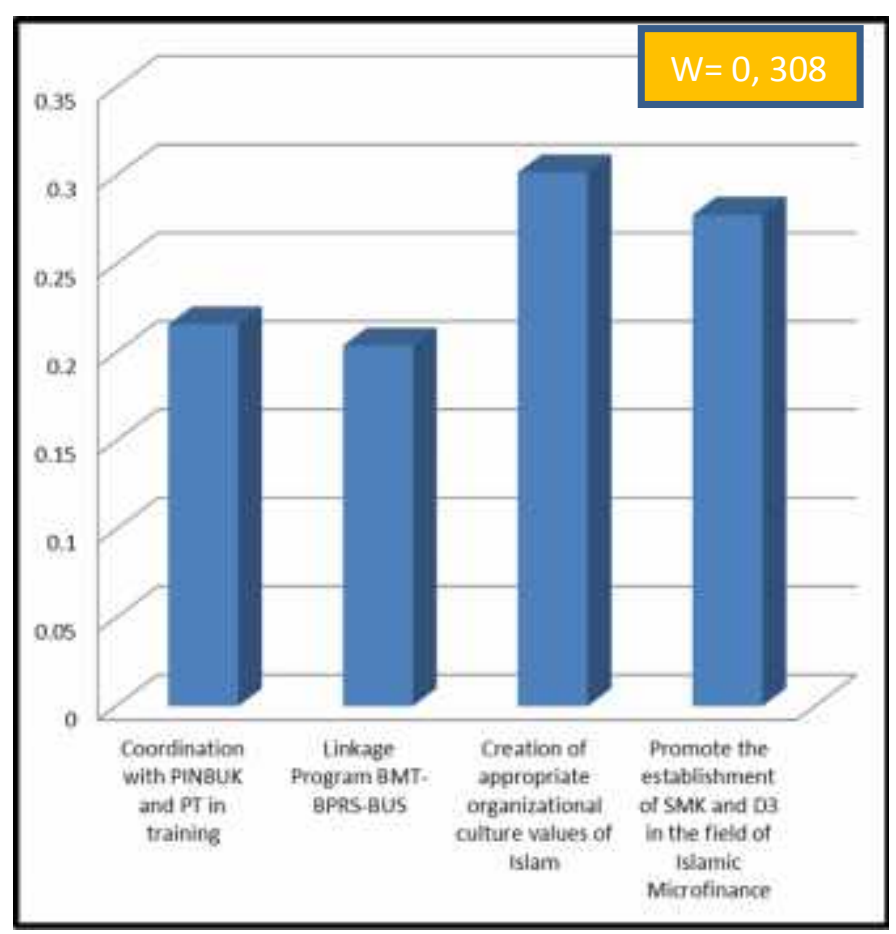

Fig 4. Strategy Priotization, Source : The Data Processing

\section{CONCLUSION}

The results of this study indicate that required the sustained commitment in developing the Islamic finance industry, especially BMT. One of the main aspects in the development 


\section{A trantse PRESS}

of this is to improve human capital performance owned BMT. Based on the results of this research note that the motivation and the Islamic financial literacy BMT employee becomes a major problem. The best solution selected by the practitioner and the expert is an employee assistance BMT, the implementation of intensive training and selection process that regard between sharia knowledge and managerial skills. The main strategy to be done is the creation of organizational culture in accordance with the values of Islam and encouraged the establishment of educational institutions that can meet the needs of human resources in BMT. Using the model of ANP, note that in general, between practitioners, regulators and academics have the same understanding in view the problems, solutions and strategies to enhance the performance of human capital in BMT. Therefore, the next step takes a real effort of various parties to improve the existence of BMT as Islamic Microfinance Institution in improving the welfare of the community.

\section{REFERENCES}

[1] Wardiwiyono $S$. Internal control system for Islamic micro financing: An exploratory study of Baitul Maal wat Tamwil in the City of Yogyakarta Indonesia. International Journal of Islamic and Middle Eastern Finance and Management. 2012 Nov 23;5(4):340-52.

[2] Sakti A. MAPPING OF CONDITIONS AND POTENTIAL OF BMT: Partnership to Expand the Market and Linkage of Islamic Banking Services to the Micro Enterprises. Jurnal al-Muzara'ah, . 2015 Jul $2 ; 1(1)$.

[3] Rusydiana AS, Devi A. Challenges in Developing Baitul Maal wat Tamwiil (BMT) in Indonesia using Analytic Network Process (ANP). Business and Management Quarterly Review. 2013;4(2):51-62.
[4] Wulandari P, Kassim S. Issues and challenges in financing the poor: case of Baitul Maal Wa Tamwil in Indonesia. International Journal of Bank Marketing. 2016 Apr 4;34(2):216-34.

[5] Abdullah F. The role of Islam in human capital development: a juristic analysis. Humanomics. 2012 Feb 17;28(1):64-75.

[6] Wright PM, McMahan GC. Exploring human capital: putting 'human'back into strategic human resource management. Human Resource Management Journal. 2011 Apr 1;21(2):93-104.

[7] Akhyar Adnan, Muhammad et.all. Study on Factors Influencing Performance Of The Best Baitul Maal Wat Tamwils (BMTS) In Indonesia. IQTISAD Journal of Islamic Economics, 2003 March ;4(1): $13-35$.

[8] Rokhman W. The Effect Of Islamic Microfinance On Poverty Alleviation: Study In Indonesia. Economic Review. 2013 Nov $1 ; 11(2): 21-30$.

[9] Haura A, Baga LM, Tanjung H. ANALYSIS OF CASH WAQF MANAGEMENT ON SHARIA FINANCIAL SERVICE COOPERATION (ANALYTICAL NETWORK PROCESS APPROACH). Jurnal al-Muzara'ah. 2016 May 25;3(2).

[10] Saaty TL. Decision making-the analytic hierarchy and network processes (AHP/ANP). Journal of systems science and systems engineering. 2004 Mar 1;13(1):1-35.

[11] Zheng W, Yang B, McLean GN. Linking organizational culture, structure, strategy, and organizational effectiveness: Mediating role of knowledge management. Journal of Business research. $2010 \mathrm{Jul}$ 31;63(7):763-71.

[12] bin Mislan Cokro Hadisumarto W, Ghafar B. Ismail A. Improving the effectiveness of Islamic micro-financing: Learning from BMT experience. Humanomics. 2010 Feb 23;26(1):65-75.

[13] Puspita KE. THE EFFECT OF INTELLECTUAL CAPITAL TO THE PERFORMANCE OF EMPLOYEES ON ISLAMIC MICROFINANCE INSTITUTIONS (Case Study on Koperasi Primer Tursina and KSU AlHambra in Surabaya). Jurnal Ilmiah Mahasiswa FEB. 2013;2(2). 